\title{
SHARED VALUE, CROWDSOURCING AND FIRM PERFORMANCE ${ }^{\mathrm{i}}$
}

\author{
Cacia Claudia, Lucia Aiello \\ Univeristy of Salerno, Via Giovanni Paolo II, 132, 84084 Fisciano Salerno \\ ccacia@unisa.it \\ Universitas Mercatorum, Appia Pignatelli, 62, 00198 Rome, Italy \\ I.aiello@unimercatorum.it
}

\begin{abstract}
The crisis currently affecting the firms, joined to the technological development and more intense global competition have transformed the current competitive environment for most firms. Firm's competitive advantage is now more dependent on continuous knowledge development and enhancement, so knowledge becomes a central theme in strategic management. Furthermore, the competitiveness of a company and the health of the communities around it are closely intertwined. The business needs a successful community, both to create demand for its products and to provide critical assets and a supportive environment and, also, community needs successful businesses to provide wealth creation opportunities. This scenario calls for a broader definition of business success which includes customer engagement methods and shifts the central goal of companies into creating shared value. This aim becomes more influential especially for those companies who operate in a new market space through electronic means that enable electronic marketing relationships from the perspective of non-conventional marketing and social-media marketing. Social Media (SM) and ICT enable the interaction with the market that allows spreading development burden amongst companies and individuals. Firms increasingly have needs of gathering ideas for innovations and providing solutions to existing problems and/or for maintaining the competitive advantage. More and more companies apply the wisdom of crowds to certain tasks and challenges, making the crowdsourcing a recognized mechanism for problem-solving. While both phenomena are not new, their overlapping requires considerable attention in practice, related to the crowdsourcing opportunities and benefits that have been enabled by new web 2.0 technologies. Crowdsourcing presents a number of potential applications, open to future developments and seem to provide new channels and ways to enable this in practice and to create new shared value and firm value. Based on theoretical conceptualization, combined with empirical evidence, we develop an analysis framework for approaching crowdsourcing in a SME context. In particular, we aim to highlight the influence of customer-social engagement through new technologies on shared value creation and stress the role of crowdsourcing process in knowledge-building process. Finally, authors analyze if those instances are able to contribute to build and develop the firm's performance.
\end{abstract}

\section{Indexing terms/Keywords}

Crowdsourcing, co-creation, Shared value, firm performance, Knowledge production, web 2.0, Social media, customer engagement, value chain.

\section{Academic Discipline And Sub-Disciplines}

Business, Economics, Technology, Organization, Cultural Studies; Finance.

\section{SUBJECT CLASSIFICATION}

Business, Management and Accounting, Economics, Organization, Computer Science.

\section{TYPE (METHOD/APPROACH)}

The paper focuses on the crowdsourcing practices that occurred within a case study. In accordance with qualitative research [1] the paper explores in depth picture of a web site, as a case study [2]. The case study [3] is bounded by time and activity, and researchers collect detailed information using a variety of data collection procedures over a sustained period of time [2] The research data include preliminary studies of the web-based context, naturalistic observations of the community and the activities of its members, and direct interactions with the members of the innovating community across interview.

\section{Council for Innovative Research}

Peer Review Research Publishing System

\section{Journal: International Journal Of Management \& Information Technology}

Vol . 10, No 4

editorsijmit@gmail.com

www.ijmit.com 


\section{INTRODUCTION}

Recently, a wide range of organisations, including enterprises, governments, academic institutions and charities, have turned to a new emerging issue that often use the internet to solve many problem. The outsourcing of tasks to the general internet public, is today an usual behavior that takes place when a subject or a firm want to solve problems that are not able to manage individually or that can be solved better with the general public (the crowd) in the form of an open call over the internet. This is called crowdsourcing promises considerable flexibility, as it quickly connects employers and workers across the globe without large difficult. Although isolated examples for crowdsourcing approaches can be found throughout the centuries [4] the development of the Internet and 'Web 2.0' technologies has drastically leveraged the reach and the efficiency of connecting with large groups of people [5]. Moreover, companies are increasingly overcoming the "not invented here" syndrome by opening their boundaries [6]. Extend firm boundaries is a key element to be innovative and competitive. The business needs a successful community, both to create demand for its products and to provide critical assets and a supportive environment and, also, community needs successful businesses to provide wealth creation opportunities. This scenario calls for a broader definition of business success which includes customer engagement methods and shifts the central goal of companies into creating shared value. Infact, in a dynamic environment, building knowledge may be more important than protecting it. This behaviors shift scholars attention to study the involvement of customers [7] [8][9][10][11]. In the last yeats many studies confirmed the strategic role of customer, considered either individually or in community context, can play in enhancing innovation and business performance [12] [13] [14] [15]. The customers involvement represent an essential issue and also a common practice for developing new original knowledge and create shared value. Creating Shared Value [11] [16] [17] [18] is essential for the firm value creation in a co-innovation view, as wevv as value creation for all stakeholders.

The core of co-innovation includes engagement, co-creation, and compelling experience for value creation [19]. In this new collaborative - "crowd" scenario, the shared value became a widespread strategy for organization oriented to develop profitable business strategies that involve customers and other new forces for innovation an value creation. According with [20] consider the relationship with clients, funders, and community managers, oriented to meet the needs of all stakeholders is the basis to understand the mechanisms of firm value creation.

When firms add to economic and competitive success the environmental objectives and social legitimacy, they enhance its intangibles as knowledge and confidence with stakeholders, creating shared value that in a co-creation context boost firm performance in different way. These new perspectives provide a multifaceted conceptualisation of knowledge sharing which presents a number of potential applications, open to future developments and seem to provide new channels and ways to enable this in practice and to create new shared value and firm value.

By drawing from recent studies we analyze crowdsoursincg and shared value concept to present some preliminary answers to these research questions: which are the opportunities and benefits deriving from web technologies? Which is the value of crowdsourcing? Can shared value really compete in generating value? what are the potential benefits of their overlapping? First, we draw from the literature review to define a deep declinations and a clear classification of "crowd". Second we propose and conceptualise the flexible value chain as key to understand the crowd" into the co-creation social value shared. The contribution of the paper is also to empirically evaluate the proposed answers to our research questions and to highlight the influence of customer-social engagement in knowledge-building process and in performance creation ability. The paper is structured as follows. First, we review three main research streams of co-creation, crowdsoursing and shared value. Second, we briefly introduce the research framework based on the practice-based approach. Third, we clarify the research design and present the findings and discussion. Finally, we provide the conclusions and address their implications for managers and scholars

\section{LICTERATURE REVIEW}

\section{The adopted perspective}

The prerequisite to the creation of value through the sharing-virtual environments, is today related to the open electronic relationships. The strong bond between the competitiveness of a company and the health of the communities around it, has boosted the studies aimed to understand how this links can be optimized. As the business needs a successful community as the community needs successful businesses to provide wealth creation opportunities. In this context, many scholars enriched the research concern the involvement of customers, other on the role of the wisdom of crowds to certain tasks and challenges, other on the crowdsourcing as mechanism for problem-solving. Others researchers highlighted the role of this elements linked to the opportunities enabled by new web 2.0 technologies and to create new shared value and firm value. In the following, we briefly introduce these perspectives and highlight the main differences and overlaps between them.

\section{Shared Value licterature review}

The crisis currently affecting the firms, joined to the technological development and intense global competition have transformed the current competitive environment for most firms. The firm's competitive advantage depends increasingly on knowledge development and stakeholders enhancement. Additionally, the competitiveness of a company and the health of the communities around it are closely intertwined. These circumstances generate a new type of business entity that has recently emerged, commonly referred to as social enterprises [21. Social enterprises, as an innovative means of solving social problems and social inequalities, calls for a broader definition of business success which includes customer engagement methods and shift the central goal of companies into creating Shared Value (SV). Porter and Kramer [22] first wrote about SV in their seminal article, in which they have proposed the SV principle as a way chosen by the for-profit 
companies engaging in strategic CSR to implement new hybrid business models [23]. SV describes the creation of both economic and social value when attempting to solve social problems, which is equivalent to increasing total economic and social value [18]. The notion of creating social value explains a deeper relationship between business and society and provides great impetus to developing social enterprises [24] [25] [26]. Wood and Leighton [27]defined social value as referring to the wider non-financial impacts of programs, organizations and interventions, including the wellbeing of individuals and communities, promotion of social capital and protection of the surrounding environment.

Other authors analyze the concept of SV [28] [16] [17]. Even Porter and Kramer expanded the idea in an article in which they stressed this concept in relation to that of social responsibility. This in a time when companies' responses to the CSR concept have been thoroughly tested and sometimes were found severely inadequate. Porter and Kramer suggest the idea that SV ensures that what is good for business is also good for others. The concept of SV «focuses on the connection between societal and economic progress - has the power to unleash the next wave of global growth» [18]. They define SV as «policies and operating practice that enhance the competitiveness of a company while simultaneously advancing the economic and social conditions in the communities in which it operates» (2011:6). It can be considered as a principle applicable to both profit and non- profit firms as well as to others type of organizations. The social purpose of SV, represents an higher form of capitalism able to create a positive cycle of prosperity.

As Porter and Kramer explains in their work companies can pursue SV opportunities on three levels: reconceiving products and markets, redefining productivity in the value chain and enabling cluster development. The first one represent a company way to meet social needs by serving existing markets/developing innovative products. Redefining productivity in the value chain, instead, represents the way by which firms can improve the quality, the quantity, the cost, and reliability of inputs production-distribution processes. Thus acting simultaneously in the economic and social development. The last one is the way by which companies operate in non-isolation from context. To compete and thrive, firms need a strong competitive context that includes reliable suppliers, functioning infrastructure, access to talent and an effective and predictable legal system [29]. The SV opportunities at each level will differ by industry, company and geography, depending on how a company's particular business and strategy intersect with social issues [30].

Contextually, authors stress the importance of the strategy in reason of the crisis currently affecting firms, joined to the technological development and intense global competition that have transformed the current competitive environment. Thus, firm's competitive advantage is now more dependent on continuous knowledge development and enhancement, and so, knowledge became a central theme for firm's strategic management. From this viewpoint, the notion of SV is related to that of alignment with market (i.e. common beliefs about behaviors, goals and policies) and customers (i.e, common beliefs on critical values like ethics, security, and privacy).

Porter and Kramer are also heavily indebted to a considerable body of theory on values, culture and its patterning and social integration (among all: [31] [32] [33]). Among all, the social theory strongly emphasizes the crucial importance of a shared system of ultimate values as an element in any society. Linked to this view Porter and Kramer argue that create SV can give rise to the next major transformation of business thinking, "drive the next wave of innovation and productivity growth in the global economy» and «reshape capitalism and its relationship to society». In other words, the concept of SV makes significant progress towards enhancing the social dimensions of business and moreover proposes to transform social problems relevant to the corporation into business opportunities.

Thus, the concept of SV is an indispensable element for the firm value creation in a co-innovation view. In today's turbulent global market, innovation became an imperative for organizational survival, and firms' strategies have to take new insights for maintain the competitive vantage. The evolution of innovation in fact, due to new technologies, modified the relations from the closed to collaborative, open, and so it have dramatically changed the dynamic nature of the global market place and also several new forces that have made innovation imperative for firm value creation. The innovation represents the results of revolution in collaboration' modality, so co-creation with consumer, that has became a worker. As a consequence the SV concept and creating SV for all stakeholders became indispensable for firms and should be a widespread strategy for every organization.

SV allow the generation of innovation in a co-making view. New ideas and approaches from various internal and external sources are integrated in a platform to generate new organizational and SVs. The core of co-innovation includes engagement, co-creation, and compelling experience for value creation [34]. The practices of co-innovative organizations are difficult to imitate by competition. Thence, it becomes more influential especially for those companies who operate in a the new market space through electronic means. These e-tools enable electronic relationships in the perspective of nonconventional marketing and social-media marketing. Social Media and ICT enable the interaction with the market that allow to spread development amongst companies and individuals. Especially in this years, firms increasingly have needs of gathering ideas for innovations and for providing solutions to existing problems or for maintaining the competitive advantage. Consequently, developing profitable business strategies that deliver tangible social value represents the roots to major opportunity for profit and competitive advantage and at the same time remains a benefits for society. Finally, although are increasing the reasons against creating SV [35] [36, the SV may well contribute to the emergence of socially beneficial business practices.

\section{The crowd-creation of value}

As the company is an institute with economic and social functions as the economic production of goods and services, that has as ultimate goal the wealth creation and of value. The value based management (VBM) is an approach to business management that has the objective of pursuing the maximization of the value of production, as well as by to define the best methods for prediction, measurement and explanation of the value. The traditional doctrine considers the creation of 
value is design and implementation of responses to the needs expressed by the market, through an appropriate use of resources. In this overview, the value is evaluated through indicators derived from accounting, such as ROE, ROA, ROI, others [37] [38]. Subsequently, the intervention of the intangible components and the emergence of new risk profiles, showed evidence of the limits of traditional models generating the need to rethink the valuation methodologies, adopting new ones, such as total shareholder value (TRS), the Market Value Added (MVA), the Economic Value Added (EVA) [39]. On the other hand, recently, the social and economic changes have led businesses to new model of capitalism and then towards new paradigms of value creation. Under these conditions the profit for the period cannot be considered representative of the long-term capacity of enterprises to create value. So, it cannot be considered representative of the long-term capacity of enterprises to create value. Enterprises must overcome the utilitarian vision and market fundamentals, placing greater attention to external variables, such as the institutional framework, the context and the collective benefits [40]. In the present day, to understand the mechanisms of firm value creation, it is necessary to consider the relationship with clients, funders, and community managers [41]; it means that firm have to meet the needs of all stakeholders.

In this perspective, the value creation ensures the development and survival of the enterprise in long-lasting, making it possible to meet the needs of the stakeholders who for various reasons add important resources for business management. Therefore, it is a long-term goal that should orient all business activities. Accordingly, the firm creates value when it directs its management towards the goal of sustainability over time, or when pursuing a development that reconciles economic, social and environmental. Economic and competitive success, social legitimacy and efficient use of resources are interconnected according to a conception of teleology and synergetic and circular business. By pursuing contemporarily social and environmental objectives, the company enhances its intangibles as knowledge and confidence with stakeholders (shareholders, employees, customers, public administration, community, others) that support the processes of value creation. The wealth thus generated (stakeholder value) is used to remunerate different social partners, who contribute with miscellaneous resources. Sustainability becomes a strategic objective related to both socioeconomic systems and businesses, to achieve sustainable economic development. This idea of creating value is in line with the other two concepts: the crowd computing and Shared Value (SV). In the next paragraphs we propose a definition of e-crowdsourcing into new perspective of SV.

\section{Knowledge production regimes declinations to a clear classification of "crowd"}

A growing amount of scientific research is focused on the analysis of new concept of collaborative fashion and other regimes of knowledge pro-duction. A consistent field of studies referred to crowd science", "citizen science", "networked science", or "massively-collaborative science" [42] [43] [44]. While it si impossible to found a unique term for these projects due to the countless configurations that can assume, we can affirm that they are characterized by important features: openness in project participation and openness with respect to the disclosure of intermediate inputs such as data or problem solving approaches [45]. This section of the paper seeks to gain a more organized understanding of "crowd" terms and its declinations to provide scholars with a conceptual framework and an agenda for future research.

We take for granted that the "Knowledge production regimes" represent the macro group in which other kind of crowd projects are enclosed. Among all, the crowd science is marked by the following feature: participation in projects is open to a large number of potential contributors that are normally unknown to each other [46] [47] [48]. Whosoever interested and qualified in a project can "entry" in it without restrictions. Generally the participation is open and based on self-selection in response to a general call for participation. Another feature that seems to be typical of crowd science project is the open disclosure of intermediate inputs used in the knowledge production, such as data sets or problem solving approaches. Generally, the inputs are part of process-related knowledge, as the possibility for project participants to discuss, develop and evaluate problem solving strategies which represent a key force of crowd science projects.

Therefore, one of the emelents that helps in differentiating the projects in regimes of knowledge pro-duction is the degree in which the features are shared. These dimensions tend to distinguish crowd science from other organizational forms, while also having important implications for opportunities and challenges crowd projects may face. The crowd projects, infact, can sketch on the effort and knowledge inputs provided by a large and assorted base of contributors, potentially increasing the range of problems that can be addressed at moderately low cost, while too increasing the speed at which they can be solved. Accordingly with Franzoni and Sauermann [45], the knowledge production regimes are defined on the basis of the degrees of openness (see Figure 1). 


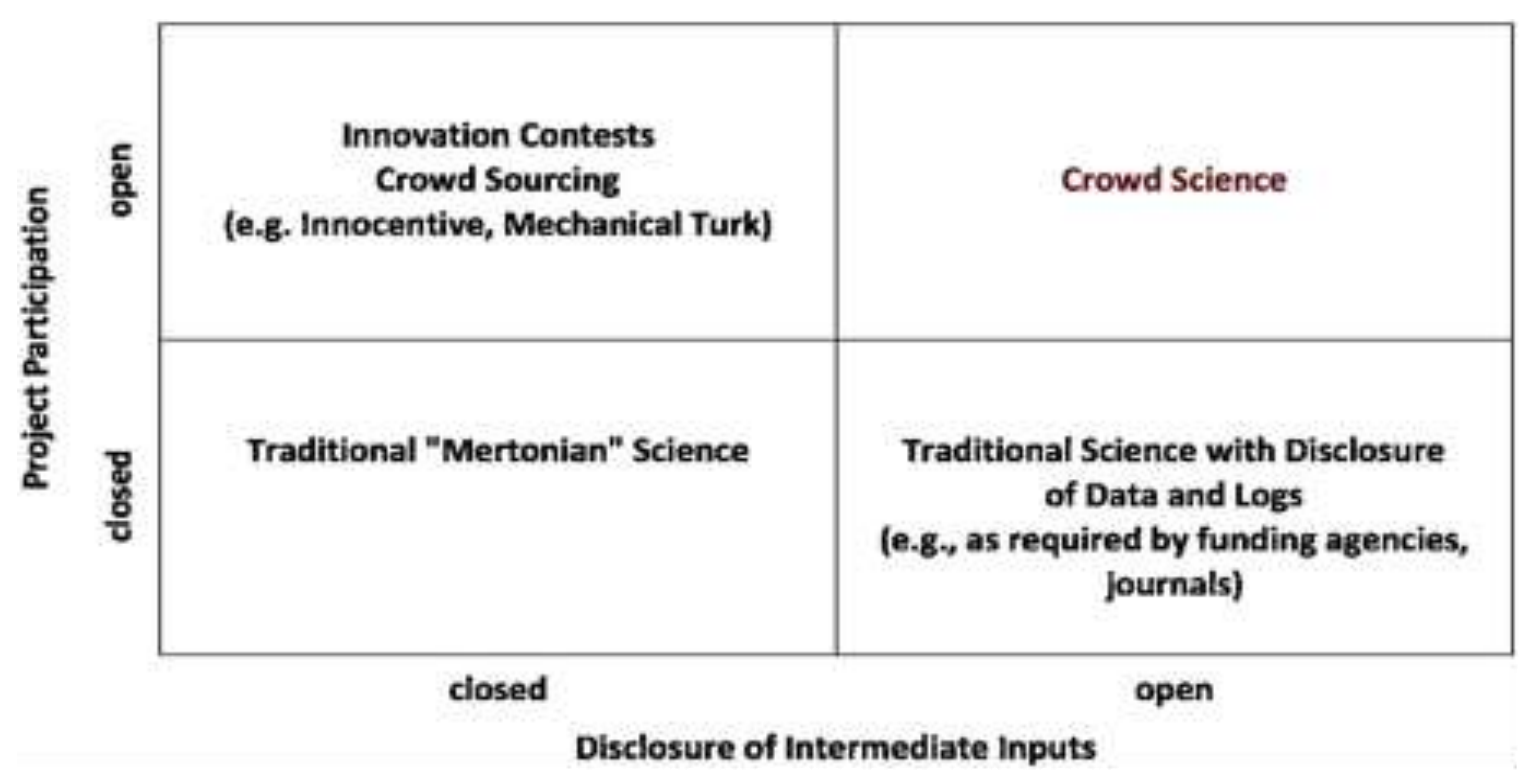

Fig. 1 - Knowledge production regimes with different degrees of openness [45].

The crowd science represents the most open knowledge production regimes and generally it is typical of sophisticated issue, such as knowledge engenders (i.e. open source software, OSS as well as production of scientific knowledge).

The traditional "Mertorian" Science, represent the classical features of the way science has been done, in which only the final results of a project is openly and publically disclosed, merely in order to obtain a reward [49] [50]. It enclosed the project in which the generation of contributes is limintated and in general closed [51] [52] [53] [54] [55], i.e. the academic or medical/laboratory research. In this area fall the project for which build a competitive advantage over rivals, represent a main concern at the expense of the progress of science. Although, the increasing use of the web and the related changing attitude to content sharing, has led many projects to move in quadrant to the "Traditional Science with disclosure of data and logs", which are characherized by a little more opened disclosure of intermediate inputs. Finally, authors define the "Innovarion contests Crowd Sourcing" in the fourth quadrant, as all projects characterized by a wide range of participants but do no publicly disclose intermediate inputs (i.e. Start up of new project or innovation contest platforms such as Kaggle). Althouth this classification help to understand the different degrees of openness in a knowledge production regimes, it do not enclose the different goal of the projects as well as the reason why the final project results is open disclosed ore not.

Hence, in our view, is important to underline another element of knowledge production regimes, that is the goal of the projects as another attribute. According to this we can distinguish between:

$$
\begin{array}{ll}
\text { - } & \text { Crowd - Sourcing } \\
\text { - } & \text { Crowd - Funding } \\
\text { Crowd - Knowledge }
\end{array}
$$

The term "crowdsourcing" [56] [57] [58] [59] has since attracted a lot of attention, even if its exact understanding still varies [60]. The crowdsourcing - that is crowd (mass, multitude) plus "sourcing", has a large reference literature [61] and, among all research in different field, exist an increasing interest even in management field [62] [63]. Generally, crowdsourcing is the umbrella term for approaches that harness the diverse potential of large groups of people via an open call for contribution over the Web [64]. The market contribution, thanks to its vast potential with various backgrounds, have recently gained attractiveness for many issues such as problem solving, knowledge aggregation, content generation, and large-scale data processing, The common principle is the market/indivifdual involvement and the freely choise to contribute to a task proposed by subjects or firms. This involvement create a process of co-creations, that has been ananlyzed from different perspective. It encompasses many aspects, like social and economic activities that are not associated with research objectives (e.g. crowd science). Generally the crowdsourcing is registered by offers oriented to knowledge and to information spread (e.g. Yahoo! answers, wikipedia), open collections of images, videos, texts (e.g. shutterstocks, Openculture, etc.), assessments and decisions through questioning the crowd, industrial and/or social innovation projects and competitions, etc. There are also crowdsourcing activities that are orientated primarily to experts and particular targets (e.g. to academics - Researchgate). Tipically, these are Internet platforms within the scope of ideas and innovation competitions often address precisely those participants that have expert knowledge and special abilities, in order to solve industrial development problems [65].

Into the broader concept of crowdsourcing, which refers to using the crowd to obtain ideas, feedback, and solutions to develop corporate activities, it is possible to insert the concept of crowdfunding, that have a unique objective of collecting money for investment, generally by using web or online social networks [66] [67]. With "crowdfunding", tipiccaly, researches refers to raising external financing from a large audience (the "crowd"), in which each individual provides a very small amount, instead of soliciting a small group of sophisticated investors [68]. Crowdfunding projects can range 
greatly in both goal and magnitude, from small artistic projects to entrepreneurs seeking hundreds of thousands of dollars in seed capital as an alternative to traditional venture capital investment [69] [70]. Who invest money in an initiative can take different forms of benefits, ranging from an equity-based model, profit-sharing scheme, and lending to outright donations [71] [72] [73] and can receive monetary or non-monetary reward (i.e.donation, future product, voting rights, or other forms of reward). The two dominant forms of crowdfunding initiatives encompasses the pre-ordering and profit sharing [74]. The crowdfunding practices (and also crowdsourcing), differs from the crowdsourcing for the unique objective and likewise from the crowd science (i.e. open source) because the resource ultimately belongs to a firm or a subject, which is the only entity that can use it. Therefore, capital is not a public good. This form of crowd are incresing in recent years and is becoming very important (i.e. the US-based projects on Kickstarter, the largest crowdfunding site, cover over $\$ 237$ million in funding pledged to 48,526 projects.) as novel way for entrepreneurial ventures to secure funds without having to seek out venture capital or other traditional sources of venture investment [70].

Finally, the Crowdknowledge represent the knowlege and information of the virtual environment. It differs from the crowd beliefs that describe the internal status of groups and individuals and of crowd intention that represents the goals of the crowd and groups of agents [75]. Therefore, the Crowdknowledge should be interpreted as the memory of groups related to the past experiences as well as perception related to agents and groups. The specific goal of this type of crowd is related to the possibility to save in the time group memory of what happen, to create new developped knowledge in the furure. (i.e. is Yahoo answer) [76] [77].

Many studies analyzed each of the previous concept, but in view of the aim of this paper we present below a brief review of main classification of crowdsourcing. The leading reference is the classification made by Howe [56] [63] who classified the crowdsoursing in the following four categories: 1) Collective intelligence (or wisdom of the crowd), in which people (in a crowd) solving problems and providing new intuitions and ideas leading to process, product, or service innovations (e.g., Amazon's Mechanical Turk ); 2) Crowd creation (or user-generated content), in which people generating countless forms of content and sharing it with others for free or for a small fee.3) Crowd voting, characterized by the ratings process (by crowd) on ideas, products or services; 4) Crowdfunding, in which people can raise financial resourse for investment, donations, or for micro-lending of funds [78].

In recent years, other scholars have also intended to identify different types of crowdsourcing research. Among all, Yuen [79] showed a literature review adopting the perspective of crowdsourcing applications (voting systems, information sharing systems, games, or creative systems), algorithms, performances (user participation, quality management, and cheating detection) and datasets. Successively, Saxton[80] built a taxonomy of nine distinct types of crowdsourcing models, basing the research on the empirical analysisi of 100 crowdsourcing organizations, that highliths three salient issues and point of differentiation of crowdsourcing firms: 1) the product or service that is being outsourced; 2) the level of collaboration 3)managerial control system. His contribution is on the identification of the role of managerial control systems, and it is deemed to be one of the most important research topics related to crowdsourcing.

A more detailed classification is that oriented to the individuation of a comprehensive characteristic able to differentiate between crowdsourcing systems along their organizational function. As Geriger suggests [64] the product or service that is provided by crowdsourcing is essentially determined by contributions from the crowd. Is therefore how they make use of contributions from the crowd to deliver the aspired result. These authors distinguish two dimensions that effectively by different contributions from the crowd determines the archetypes of crowdsourcing (see Figure 2). The first is the typology of contributions: homogeneous (when contributions have all value equally, and are qualitatively identica) vs heterogeneous (when contributions values these contributions differently according to their individual qualities). The second dimension is the value deriving from contributions: nonemergent vs. an emergent value. A value is non-emergent value when derives directly from all or some of the individual contributions in isolation, as a fixed value and independent of other contributions. In contrast, an emergent value is that deriving from the collective of contributions and the relationships between them (do not exist individual contributions. Combining these dimensions they defines the first archetype of crowdsoursing as "Crowd Processing", where the non-emergent value derives directly from large quantities of homogeneous contributions. In this case the crowd help to find a quick and efficient solution to a problem (e.g. Galaxy Zoo, or Recaptcha). The as "Crowd Solving", instead, highlights the alternative isolated values of heterogeneous contributions to resolve problems (e.g. 99designs, eYeka, Hatchwise, DesignCrowd, Zooppa, etc.). The "Crowd Rating", instead by aggregating a sufficient number of these votes, allows to these systems accurately deduce a collective response that reflects the "wisdom of crowds" (e.g. TripAdvisor). Finally, "Crowd Creation" derives from the accumulation of a mixture of heterogeneous contributions and their interaction. In this archetype the crowd/users are able to creates contents (e.g., app stores) or knowledge aggregation (e.g.,Wikipedia). 


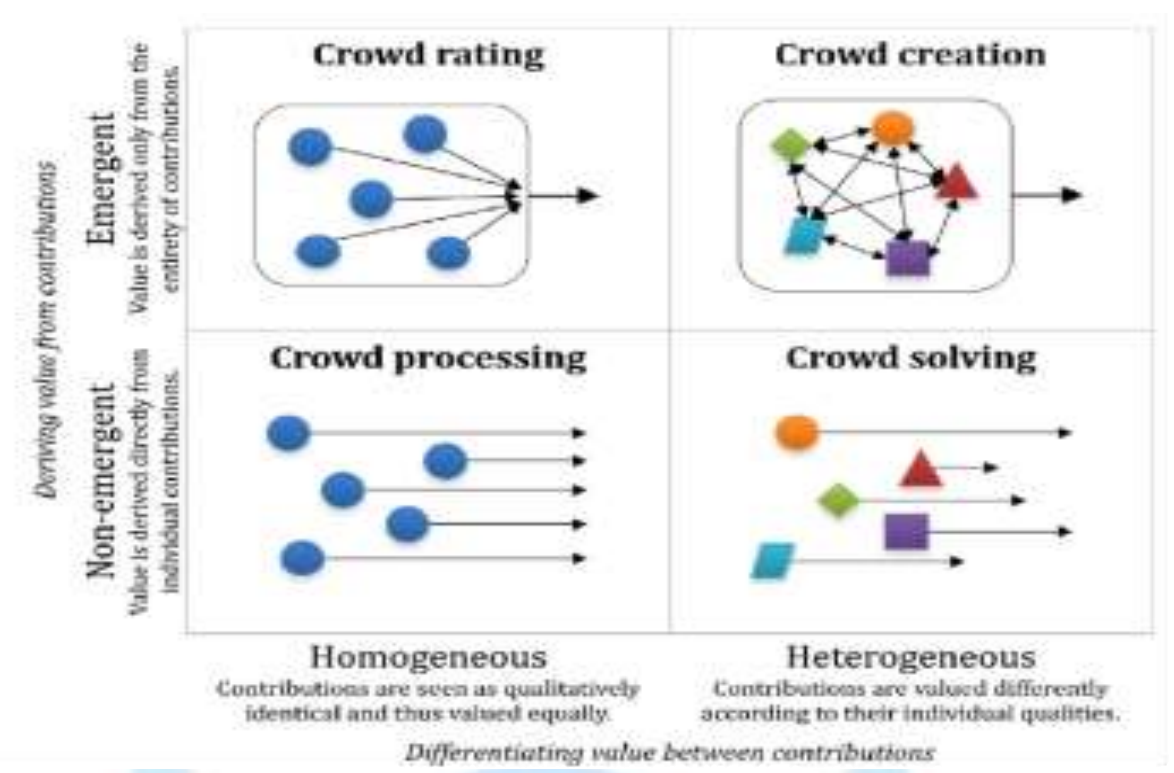

Fig. 2 - The four archetypes of crowdsourcing information system. [64]

All those distinctions of typologies provide structures to organize the body of knowledge and to study relationships among otherwise disorderly concepts [81]. In our view, the last presented helps to understand the importance of the bidirectional relation between firms and market or stakeholders as the via to create shared value. Accordigly, in the follow section we discuss the Importance of customers, labor and management of collective intelligence to achieve explicit business goal.

\section{Crowdsourcing: the role of web customers for sharing value}

The changing environment condition have bring companies to employing new models and toos to make rapid decision and solve problems [78]. In this context, the customer involvements has became an essential success key [82] . Therefore, it is important to underline the role of consumer in organizational desingn. The crowdsourcing by means of customer engagement, is also known as open-innovation [83]. It is an emerging paradigm that is changing the way business is done and represents an emerging problem-solving and co-production model [84]. Companies can and should use external ideas, in addition to internal ones, to facilitate innovations, share risks, and improve productivity and competitiveness [11]. Several other methods and tools have been developed to render similar concepts: co-creation, that differs from crowdsourcing by the depth and richness of the relationship between the producers and consumers [10] [85]. user innovation [7], collective intelligence (is considered a common type of crowdsourcing and harness the collective intelligence of people as a computer-based crowdsourcing) [61]. By the way, some scholars suggest that customer engagement is necessary for positive word of mounth [86], customers loyalty and commitment to the brand [87]. So, the consumers involvment is strategic issue for companies that increasingly outsource activities to volunteers that they approach via an open call on the internet.

In this regards, the crowdsourcing become a process of work that is based on web. So, the crowdsourcing requires that the user propose an idea to employers, which realizes that. In this sense, they create a firm's value creation process. Clearly, the user may be an employee, a loyal or potential consumer, but it is important sharing of the idea, that becomes a product and then value for the company, for the worker or/and consumer. The importance of digital technology was often noted as a precondition for many new forms of self-service, as in the example of observations of services offered by mobile telecommunications companies. A «new type of prosumer» was discovered among cell phone service users, whose activities and skills are very similar to those of the information technology professionals who nominally provide those services [88].

Thanks to the web 2.0, the potential of the environments in which individuals (consumers and labor) can create value was expanded, by amplifying the opportunities for contact and interaction of the physical environments. Currently, the consumer has a voluntary role, although its role can be decisive in the actions of impulse to certain actions to improve the performance of process or product [89]. Unlike outsourcing process, into crowdsourcing the project is outsourced to an indeterminate group of people and not to a specific individual. In the literature, there are different guidelines on the roles of those involved in the project, the debate is whether to consider them: workers or volunteers.

Considering the crowdsourcing as a way in which the partners involvement is symmetrical, to find solutions and ways to improve processes and products, and consequently organizational efficiency and consumer satisfaction. Therefore the consumer-firms relationship have the aim of create value with consumer, thus it is possible to define hybrid figure: that of the worker-consumer [90]. Three characteristics of worker-consumer are central to an ideal-typical definition: a) working consumers are active in the production process and can be utilized as value-adding workers; b) the capacities they possess are valuable economic assets; and c) they are systematically integrated into corporate structures, where their actions can be monitored and manipulated by corporate managers as if they were employees. 
Accordingly, the definition of voluntary (free labor) - unpaid worker or voluntary - provides by the ILO (International Labor Organization) could include these individuals in this category. If there isn't the payment, however, there may be the interest to ultimate objective: to create value non-economic for themselves. The creation of value can arise from two possible modes: 1. participate in the project, 2. consume the final product resulting from the project. Reichwald and Piller [91] differentiate between two forms of crowdsourcing: mass customization and open innovation [92]. «The problematic possibility that firms may be able to manipulate individuals' cost-benefit calculations falls outside of the paradigm. Yet, corporate consultants openly discuss crowdsourcing as a model in which participating consumers get absolutely no benefit from their participation. Customers who submit their ideas rarely receive adequate financial compensation for the work involved in doing so» [66].

Therefore, crowdsourcing provides for the involvement of a community in the development of an idea [93], and this can generate social innovation [94]. Societal changes have induced a paradigm shift from product-driven to service-dominated value creation. The multiple theories that encompass the consumer in the product's creation describe a new division of labour between firms and consumers such that consumers become active contributors in the creation of value.

Finally, although research on consumer has paid little attention to fundamental changes in corporate-consumer relations [95] [96], other researches began to draw attention to these phenomena. Thus, there is a new empowerment for stakeholders, thanks to the increasing of web and e-environmental. Co-create value for enterprise [97] across to the increasing of co-participation, interaction and value fulfillment is very strategic in the organizational policies [98]. For this reason, it can be adopted that participatory tools (i.e. Social Network, Platform, Wiki) can boost relationship drawing on the wealth of knowledge generated by customers. This could be able to influence the enterprises' ability to identify new patterns of value co-creation.

\section{Participatory tools to value creation}

The evolution of the digital era, which allows to define the concept of space-action, pushes the corporate organizations to pursue emerging strategies in able to share the value chain (VC) along the orientation of the company. The use of webbased tools is necessary because it allows: 1. flexibility, advantage of having a greater space-time; 2. collaboration, sharing opportunities and interaction 3. accessibility/opening, this opportunities lets to consumer and to any external individuals - that can bring added value to the value chain - for be included in the organization model. The variable on which you want to act is the individual (human resource and consumer) and as the individuals who make up the crowd contribute to the value chain [30], so creating shared value [99]. As traced in the introduction, we want to provide a possible definition of e-crowdsourcing, starting from definition of Interaktive Wertschöpfung [91]. The authors define the interactive value creation in the same way wherewith they define the crowdsourcing. In fact, the definition is «the act of taking a job traditionally performed by a designated agent (usually an employee) and outsourcing it to an undefined, generally large group of people in the form of an open call» [100:87].

In the transition from the crowdsourcing at the e-crowdsourcing, the crucial role is that of the space-action (physical environment + virtual environment), since in the proposed definition, the company is facilitated in the creation of interactive value across new places. The physical environment and the virtual, therefore, can become the places where the human resources can to actively interact with the consumer without being on several fronts, but on the same line, to cooperate to achieve the same goal: to create value. The considerations now outlined, lead to reflect on the fact that, in order to define the e-crowdsourcing, you must define the virtual environment as a virtual place where the company meets the crowd and, with it, builds the product, the brand, the processes. In this case, the "e-" indicates the virtual space in which stakeholders can interact actively. In any case, for Kleemann, Günter Voß and Rieder [66], the act of the creating value is modified from the firm-dominant process at the process of co-production or co-creation with the active participation of customers and other Internet users.

This approach, again for the three German authors, is identical to the concept of consumer-worker of Voss e Rieder [90], which describes a new division of labor between firms and consumers so that consumers become active participants in the creation of value. The additional step, however that Reichwald and Piller [91] make, through analysis of issues relating to the cost-benefit of crowdsourcing, is that this new concept is only possible when the costs are low and the necessary interplay brings benefits to all participants. In this case, the two perspectives are different and the action of sharing and interaction business-consumer is different. The cost-benefit analysis can become the central point of this difference. This means that there is crowdsourced if there is interaction in virtual space, generating lower costs for the company, the sacrifices are minimal for consumers and the benefits are for all participants.

Clearly, at the basic of e-crowdsourcing, there are also services that are basic ICT platform, which must be the container of data and information back-office organizations in the supply chain, facilitating the sharing of information and ensuring the safety of data. Reichwald and Piller [91], also consider, that there are two different forms of crowdsourcing: mass customization (mass personalization) and open innovation. The first type refers to the valuation of transactions in order to allow individual buyers to purchase a custom product just for them. The open innovation, on the other hand, refers to the cooperation between a company and its customers in the development of a new product for the benefit of a mass of potential buyers. For Kleemann et al., [66] only cooperations with the crowd (mass) may fall within the definition of crowdsourcing, therefore, in this context will be considered only the open innovation that, through this work, we consider open innovation in the e-space. The cooperation for innovation, in this case, takes place in the web 2.0, where users do not need to be mere recipients of media content, but they can actively participate in its creation through activities such as blogs, forums, social, etc. The technical assumption needed for these activities is social software, or applications that allow you to communicate, interact and collaborate in virtual space [101]. 
In this perspective, it is important focusing the analysis on the role of social technology. The crowdsourcing, through the New Technologies (NTs) web-based, have facilitated value creation and organizational efficiency. In this perspective, the NTs have supported the diffusion of crowdsourcing, and they involve different tools and individuals [102]. Reichwald and Piller[91], who place the phenomenon in an economics framework, have proposed the use of the term Interaktive Wertschöpfung (interactive value creation) as a synonym for crowdsourcing [103]. Accordingly, people are overcome resistance phase. The main barriers to the use of this modality have been overcome. For example, a particular organization as Publishing Houses are considering the opportunity to create environments in which the researcher, in the role of author, can freely sharing his knowledge with his colleagues, and vice versa. In start-up phase they wonder if: «is crowdsourcing a win-win for workers, as well as for employers?» or «is the customer a worker no-pay?», actually it is a necessity by consider: twhether here are benefits for consumers in the role of workers. In the context of this research, we consider the opportunity to be key player of organizational processes, participating in the creation of shared value. The speed with which the issue is affecting employers, workers and customers, asks to provide the paths on which the literature has developed, through a reconnaissance (see Table 1).

Table 1. Crowdsourcing: perspective and literature review [99]:4613.

\begin{tabular}{|c|c|c|c|c|c|}
\hline $\begin{array}{l}\text { Crowdsourcing } \\
\text { its approaches }\end{array}$ & Perspective & Contribute & Authors & $\begin{array}{l}\text { Line of } \\
\text { research }\end{array}$ & Case Studies \\
\hline $\begin{array}{l}\text { Role of NT to } \\
\text { support of } \\
\text { crowdsourcing" } \\
\text { diffusion }\end{array}$ & $\begin{array}{l}\text { (1) "Social } \\
\text { software" or } \\
\text { applications that } \\
\text { enable } \\
\text { communication, } \\
\text { interaction, and } \\
\text { collaboration } \\
\text { through the internes }\end{array}$ & $\begin{array}{l}\text { (1) Internet is not only } \\
\text { about new technical } \\
\text { posssbilatics } \\
\text { communication }\end{array}$ & $\begin{array}{l}\text { (1) Steg-bauer/Jiskel, 2008; } \\
\text { Alby, 2006; O'Reilly, 2005; } \\
\text { Hippel 2005; } \\
\text { Chesbrough, Vanhaverbeke \& } \\
\text { West, 2007; } \\
\text { Drossou, Kfempl \& Polier-mann, } \\
2006 \text {; } \\
\text { Chesbrough, } 2006 \text { and } 2007 \text {. }\end{array}$ & $\begin{array}{l}\text { User-generated } \\
\text { content, the } \\
\text { creation of } \\
\text { claborate } \\
\text { platforms for } \\
\text { interaction and } \\
\text { networking, and } \\
\text { wer-friendiness }\end{array}$ & $\begin{array}{l}\text { Platform of } \\
\text { Mulino Bianco } \\
\text { www.nelmalinoc } \\
\text { hevorrci.it } \\
\text { Platform of } \\
\text { Userfarm } \\
\text { hitp:/www_userf } \\
\text { armeomvit/page } \\
\text { video-crowd- } \\
\text { sourcing }\end{array}$ \\
\hline $\begin{array}{l}\text { Role of } \\
\text { consumer in to } \\
\text { organizational } \\
\text { planning }\end{array}$ & $\begin{array}{l}\text { (1) Consumer } \\
\text { behavios and } \\
\text { "service "Customer } \\
\text { encounters" } \\
\text { (2) "Cevelopment" } \\
\text { dist participants } \\
\text { (3) Consumers as } \\
\text { joint the firm in } \\
\text { with "Partiar" } \\
\text { value creation } \\
\text { (4) employees'unpaid } \\
\text { employees }\end{array}$ & $\begin{array}{l}\text { (2) Interactive value } \\
\text { creation } \\
\text { (3) Consumers as joint } \\
\text { participants with the } \\
\text { firm in value creation } \\
\text { (4) Consumer } \\
\text { employess }\end{array}$ & $\begin{array}{l}\text { (4) Mills \& Morris 1986; } \\
\text { Nerdinger, 1994; Hane-kop, } \\
\text { Tasch \& Witthe, 2001-91; } \\
\text { Hanekop \& Witke, 2005; Dunkel } \\
\text { \& Vo8, 2004; Ricder \& Laupper, } \\
\text { 2007; } \\
\text { (5) Franik Kleemann, G. Günter } \\
\text { Vo\& \& Kerstin Rieder (2008); } \\
\text { Voll and Rieder (2005); } \\
\text { Scherhorn } 1977 \text {; } \\
\text { Rosenkrana Schnei-der 2000; } \\
\text { Offe Heinze 1990; Ritzer (1983) }\end{array}$ & 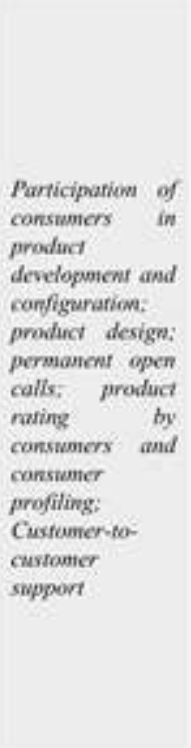 & 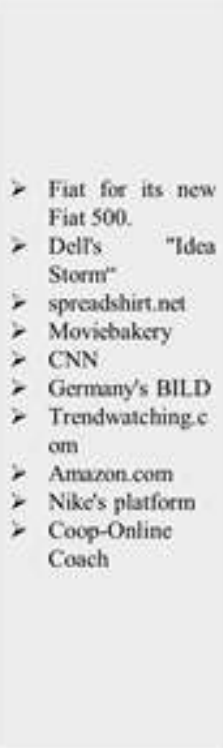 \\
\hline
\end{tabular}

The web 2.0 initially seemed harmful for companies, since it has allowed the spread of open sourcing. Subsequently, the open-sourcing has permission to the organizational process of crowdsourcing to be able to become more efficient. Today we can say that the environments virtual open involves benefits for both parties that used it (as consumers, firms). In this perspective, the crowdsourcing is «the clearest example of how firms can mobilize internet users to make a direct contribution to its processes of value creation» [66]. In effect, «Firms are shifting a wide array of previously internal capacities and functions onto their own customers, consumers in general, and other non-employees. This trend is affecting an increasing number of areas and is being conducted increasingly systematically" [66]. The integration of strategic and organizational theories, from the perspective of the firm and the consumer, in the range of web 2.0, permits to reflect on the role of the value chain (CV), thus no organization can achieve its mission if it not define the model of contribution of value.

\section{FLEXIBLE VALUE CHAIN AND ROLE OF THE “CROWD” INTO THE CO-CREATION OF SOCIAL SHARED VALUE}

Kaplinsky and Morris [104] , have analyzed the question of one or more value chain, after more than 10 years the question on value chain evolved. The Twenty-first Century is been mark out from a very evolution of value chain, through New Technologies [105]. 
Thus, the strategic topics are the flexibility's role [106] and the co-creation of value chain [107]. Thus, they can assert that in the value chain is possible that the traditional parts (workers, managers, suppliers, clients), can invert the position [105] [108] [109.] In licterature, the authors consider «Knowledge creation and diffusion is a process happening within the value chain of firms is of great importance» [110:1116]. In a first analysis they can consider that the flexibility is affected «from geographic proximity of the various elements of the value chains seems to be a main reason for the concentration of innovations (...) The knowledge economy is undergoing a process of differentiation and spatial segregation leading to a constant rearrangement of the value chain of knowledgeintensive businesses» [110:1117].

The research question is the proposition of the crowd as facilitator to co-creation social value shared. The co-creation, amplified by innovation, allows you to renew the existing models of the value chain [107], this allows to have input from users and, therefore, an active role of all actors of the value chain. The consumers and the suppliers, which were static subjects of the process, are now active subjects. This depends that general views on value creation are evolving toward a service-dominant logic (SDL) view, which focuses more intently on collaborations aimed at the sharing of specialized competencies among actors functioning in a network. The contemporary view of value creation based on competencies and SDL [111] [112] and DART (dialogue, access, transparency, and understanding of risk-benefits) SCM (Supply Chain Management) practices [113] as enablers of value co-creation [114] (see figure 3). Greenberg [115], affirms that hrough an SDL lens, co-creation is not a temporally bound phenomenon, but rather can take place in a time-shifted or even placeshifted way. Lusch, Vargo [116], have analized the notion of value co-creation through the exchange of specialized knowledge and abilities.

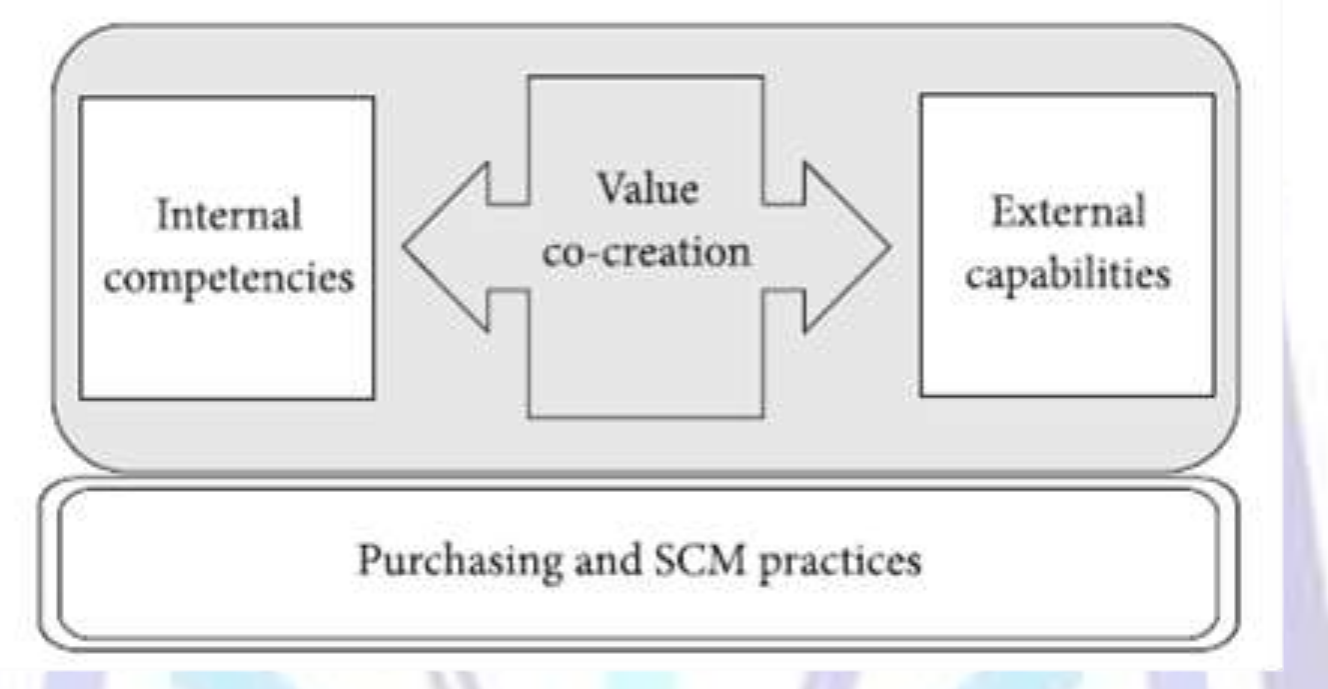

Fig 3: Conceptual model of the competency - capability transformation during value co-creation in SCM practices Chakraborty, S., Dobrzykowski, D., 2014: 182

Along the value chain, horizontally or vertically, between different subjects there is sharing information and knowledge that impact on value creation. Thus, we can affirm that there is a link between SCM practices and value co-creation exchanges; the competency - transformation capability [114], Into value chain that they have considered there is shows a value co-creation between internal competencies and exernal capabilities in DART SCM practies.

The study of "crowd" theory requires the DART SCM approach, because it is cross-functional and involves several actors, they have different competencies and different relationships (involving supplier, customer, institutions, others). In according to Lambert from the SDL this involvment and thus, the co-creation value chain affect on capacity to create adds value for customer and other stakeholders [117]. Certainly then this convergence towards integration and value creation links SCM processes by SDL. Thus, the "crowd-theory" has to allows the dialogue, the access, the transparency, and the understanding of risk-benefits between all parts involved. Since, the DART can create confidence and social identity. The SCM (Supply Chain Management) practices is foundamental because the logic to based of the "crowd-theory", that we proposed through this work, is supply of knowledge/sourcing/funds/others be-directional between the persons involved. The role of crowd on value co-creation is on based of this research, [114] on verify that value co-creation requires a multipronged approach. An interation network how "crowd" allows access to information, a willing dialogue among actors, transparency, and the ability to make risk-benefit assessments regarding participation in the network.

The "crowd" stimulates the co-creation and involves more persons that, in different conditions, not would be connected; this opportunity is the base of shared-value co-creation approach that we propose through this work. The authors consider that through "crowd" they can obtain the quality improvement using consumer knowledge, «In the context of integrating customers into productive processes, companies can make use of customers' expertise - in the use of company products, for example. In this way, customers can contribute to the betterment of product quality» [66:20].

Cachon, G. P., and Fisher, M. [118] argues a link between SCM and SV, since the «implementing information technology to accelerate and smooth the physical flow of goods through a supply chain is significantly more valuable than using information technology to expand the flow of information» (1032-1048). The crowd-theory supports the opportunity to 
create Shared Value (SV), in line with this paper the future for entrepreneurs is the innovation, as crowd e-platform, and relationship to society, as interactive with crowd. Thus, all parts of SC can transform social problems relevant to the corporation into business opportunities. Two conditions support this perspective: 1. Social needs are fragment and crumble; 2. Virtual environment builds on homogeneity can draw more individuals that have similar needs. This two point foster the opportunity to create new idea, so value creation [18], in advanced sense value co-create from and for society.

\section{RESEARCH METHODOLOGY, DATA COLLECTION AND ANALYSIS}

This study adopts the qualitative method of case studies, according with the nature of the subject investigated. As numerous researchers suggest [3] the qualitative methods are useful for obtaining a new understanding of existing phenomena. In this view, data and methods are strategic for an exploratory empirical study.

The goal of this paper is to develop initial evidence about the nature of platforme "crowd" and its role in entrepreneurship research and co-creation. This method is appropriate for an evolving topic in the evolving field of entrepreneurship [119] [120], as this initial data can serve as a useful base for future theory-building [121]. Thus, rather than formal hypothesis testing, the remainder of the paper will examine the key issues around "crowd" from the perspective of entrepreneurship: its links to existing theory, the perception and expectation of entrepreneur on platforme crowd.

As the goal of this paper is to provide the widest possible perspective on platform "crowd", we used data extracted from a survey administer to members of an e-commerce platform. This choice depends from needs to investigate the perceptions, expectation and opportunity of crowd-platform for the entrepreneurs, that utilize the internet and webplatform. The case study was organized by in-depth interview with e-commerce platform manager also, non participant observation of the investigated platform. The case study, that follows, is structured in coherence with Yin [3] infact, the components of research designs are, in according to study, the questions, study propositions, unit of analysis the case, linking data to propositions, criteria for interpreting a case study's findings [3].

The questions are: the entrepreners have the need to co-create?; the platform and web is a percepited as an environment where make co-creation?; what is the perception of platform crowd from entreprener?The study propositions are the proposition of the crowd platform as facilitator to co-creation social value shared. The unit of analysis the case is the all entrepreneurs that are affiliated to platform Lux Made In. Linking data to propositions is inspect to development potential of crowd platform for co-creation in line with flexible value chain and social value shared (co-creation with consumers, competitor, others). Criteria for interpreting a case study's findings is data and informations analysis.

The steps doing case study research require a linear but iterative process, thus plan, design, prepare, collect analyze and share. The plan of research involves identify the relevant situation for doing a case study, compared to other research methods; understand the two-fold definition of a case study inquiry; address the traditional concerns over case study research; decide whether to do a case study; the tools is a survey. We preferred this method because the main research questions are "how" or "why" questions, the researcher has little control over behavioral events, the focus of study is a contemporary phenomenon [3:2]. The case study shows the explanatory and not just descriptive or exploratory functions of single-case studies. Researcher [122], forcefully demonstrates how a single case study can be the basis for significant generalizations. Survey must be respond to questions that follow: who, what, where, how many, how much?. This case study, in line with mains authors on topic, not requires control of behavioral events, and it is focused on contemporary events.

The case study is utilized because we present an exploratory research through case study within a survey. The questions of the survey are those the most pressing on the topic, as well as to gain some precision in formulation these questions, as required from the main litterature [123]. Some questions are "frequency usage Internet and platforms", "expectations and motivation of respondents to adhere to "platform"' and "the need to co-creation".

Since the question research on shared value, crowdsourcing and firm performances is be at an early stage we have considered that the survey must been building on perceptions and acspectative of utilizers of web-platform (i.e. ecommerce platforme). The scope is verify the attitude and needs of this individuals on co-creation and crowd platforms.

We chose the companies through an internet search by keywords (e.g. e-commerce, crowdsourcing and co-creation) to find wealthy case studies [124]. Based on previous research approaches who state that due to limited time and poor resources and also thanks to the assumptions of Stake [2] [125], we have chose "Lux Made In" case study in a limited period of 6 months. This choise depend from need to analise how the web users perceive and what they await from the web-platform and the crowd-platform.

\section{Case Study: Lux Made In}

The platform Lux Made In is a project of the association Young Jewelers in Italy. The association is independent and the its target is the new generation of Artisans and Professionals of Micro, Small and Medium-sized enterprises Jewellery made in Italy. It ia an online sharing platform, where involved subjects ezperiments with new way to relate itself with peers and customers.

The network includes the entire chain of Jewelry and Accessories area, artisans of Luxury Made in Italy, goldsmiths, designers oiovani, second Generations of Jewelers, new entrepreneurs in the industry, retailers of jewelery, watches and accessories, and Micro, Small and Medium Enterprises. The mission is the development and promotion of creative excellence, artistic craftsmanship and the production of Made in Italy luxury, encouraging the sharing of experiences, 
know-how, market information and innovative proposals among the young actors in the sectors Jewelry, Watches and Accessories, favoring bonds of friendship and cooperation.

The Lux Made In is the first digital district of the districts of jewelery made in Italy in line with the mission of the association to encourage the sharing of experiences. The case study is positioned between a digital platform integrated of Social Network and crowd-platform. The choise of case is that the research question is verify the "Feelings of belonging and the expected benefits from the Social Commerce Platform" and if the social commerce platform can be able to a platform crowd.

The methodology of case study is been supported from questionnaire administered to members of social commerce platform; the feedback is $100 \%$ of interwies. The quetionaire is elaborated on three parts: 1 . member of platforming profile; 2. expectations platforms crowd; 3. perception of the platform Lux Made In; 4 expectations platform Lux Made In. The results of the poll is presented into the graphs and into the informations elaborated to following. The questionnaire was administered in October 2014 at all the participants of the ecommerce platform Lux Made In with a response rate of $100 \%$.

The first part of the questionnaire has aimed to profiling the members of the platform. The figure number four, "graphcake" points out how often they use the Internet and web-platforms; the "chart cones" makes the profiles the respondents by gender and the frequency.

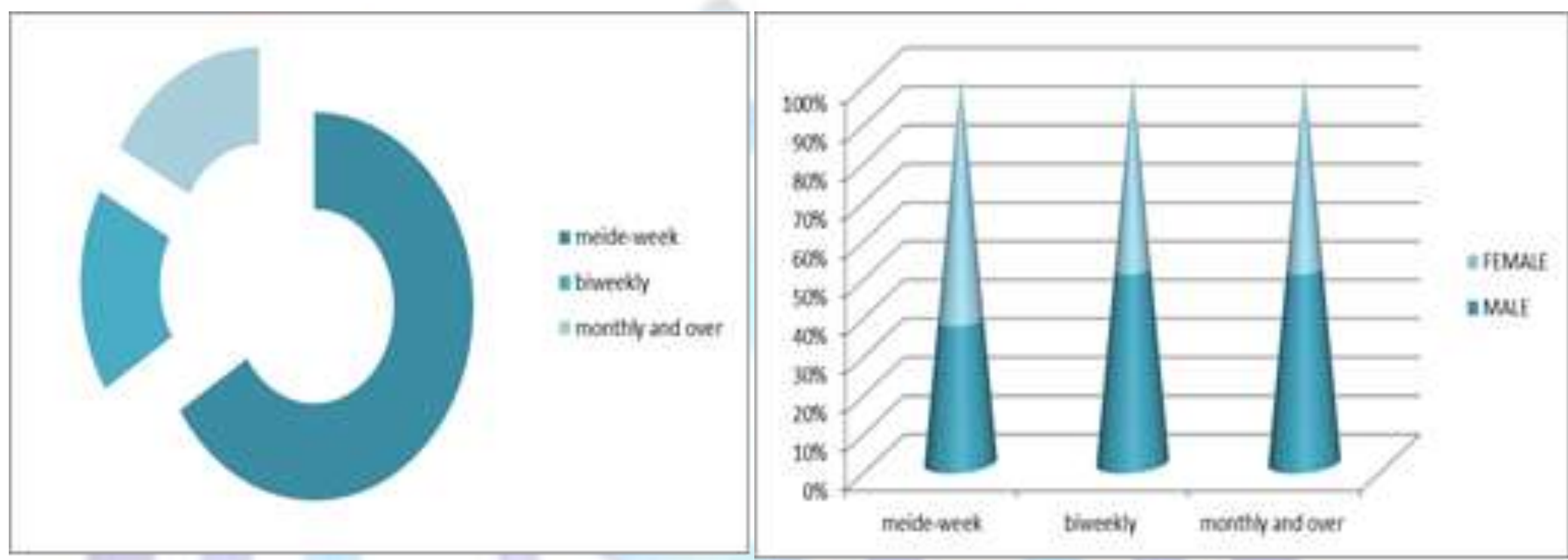

Fig 4: Profile of respondents: frequency usage Internet and platforms for gender.

The figure 4, shows that respondents are active on the web, and an important note it is that the women (meide-week) are more active on the web than men (biweely and monthly and other).

In the followng figure (see figure 5) we can consider the expectations and motivation of respondents at adhere to webplatform, the respondents are all member of e-commerce platforme we want verify the motif that encourages a person to participate to web-platform.

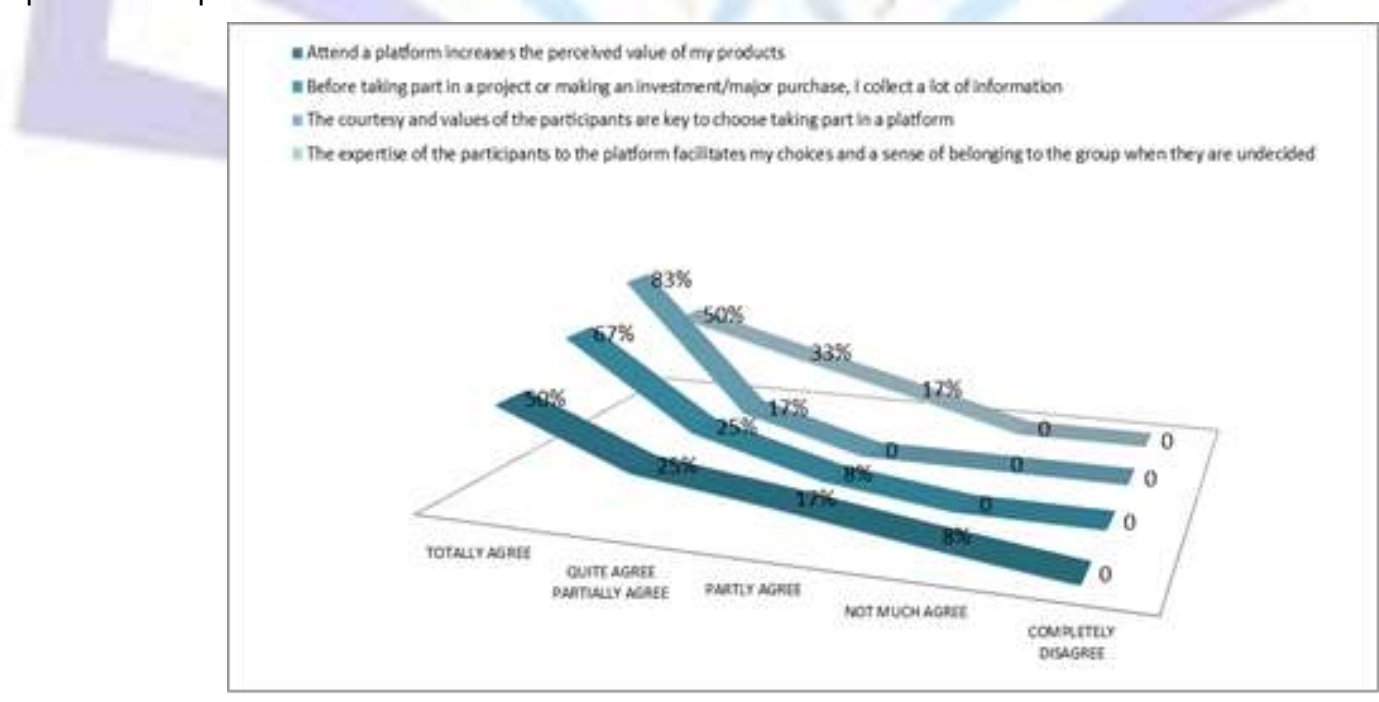

Fig 5: Expectations and motivation of respondents to adhere to "platform" 
The $83 \%$ of respondents affirme that the courtesy and values of the participants are key to choose taking part in a platform. The $67 \%$ of respondents deem that before taking part in a project or making an investment/major purchase, I collect a lot of information. The $50 \%$ of respondends consider that attend a platform increases the perceived value of my products and that the expertise of the participants to the platform facilitates my choices and a sense of belonging to the group when they are undecided. The results of the questionnaire reveal that the platforme are perceived to present the products and compare prices, but also, significant element, to need to exchange ideas with others, such as peers and clients. With respect to the technical features of the platform, almost all of the respondents believe that a platform should have a help desk and a real-time assistance. An important result is that the respondents claim that the tradition of the sign/shop and participants and confidence in colleagues who sell the same platform are among the main reasons in choosing to become a member of a platform.

The $100 \%$ respondents consider that the platform "Lux Made In" could to be Able to a platform crowd, despite only $10 \%$ of respondents said they knew what a platform crowd. This means that you need a more tacit and unspoken but need to share in order to grow and to create value has emerged from this study. Thus emerged the need to co-create:

1. the jewel with the consumer;

2. with the designers who are in different physical locations;

3. co-branding with the other participants to the platform;

4. collections with competitors.

The results of this first step of survey take off the link between the need of co-creation and value creation. The entrepreneurs want the "crowd" and they perceive that this impacts on value creation. In according to this overview tha $90 \%$ of sample consider that appartenere alla piattaforma Made Lux In in improved performance and results of its own and other participants. The shared value became a widespread strategy for organization oriented to develop profitable business strategies that involve customers and other new forces for innovation an value creation. Thus the respondents want a relationship with clients, funders, and community managers, oriented to meet the needs of all stakeholders is the basis to understand the mechanisms of firm value creation.

\section{DISCUSSION AND IMPLICATIONS OF THE MAIN FINDINGS}

The results of case study demonstrate that the firms add to economic and competitive success the environmental objectives and the social legitimacy, they enhance its intangibles as knowledge and confidence with stakeholders, creating shared value that in a co- creation context boost firm performance in different way. These new perspectives provide a multifaceted conceptualisation of knowledge sharing which presents a number of potential applications, open to future developments and seem to provide new channels and ways to enable this in practice and to create new shared value and firm value.

The opportunities and the benefits deriving from web technologies are in growth, they allow new opportunities to interact and create value. Thus, the members of Lux Made In have declared these needs. In them perspective, the new opportunities of web-platform is the value of platform-crowd through co-creating, and this can be shared value really compete in generating value. They perceive the potential benefits of their overlapping, and they meet and create new needs that can increase the profits. Since the "Lux Made In" has affected on the increase of profits, the members consider the potential of crowd-platform. This is put in evidence from the request of co-creation with new individuals through the platform "Lux Made In (LMI)". All members of platforme (100\% of sample) require to administrator of LMI to strenghten the opportunities of interactions and involvment of more parts (competitors, consumers, others individuals).

The limit of this work is that the case study not is on platform crowd but on the e-commerce platform and perception and expectation of its users on platform crowd, becouse this study is into embrional step. In future research we will propose, in accordance with Kozines [14] the netnography research will include studies of the platform crowd. In detail, through observation of the community and the activities of its members and direct interactions with the members of the co-creation. The observation of interacions between all participant and a multiple valid sources "each of which helps us to gain a better understanding" of the investigated phenomenon [126] Since, Richardson (2000) suggests that is fundamental the data collected from these web contexts with data from various documents, reported cases and other related materials. We initially analysed the data on an intra-case basis to investigate the phenomena. Subsequently, a cross-case analysis was performed to develop an overall view of the matters under investigation and to compare the cases.

The paper presents the first results of an ongoing research that need to be depended to cover other kind of organizations and business sectors. Despite these limitations, some conclusions and managerial implications can be derived at this stage of research. Seeing as, crowdsourcing is an emerging area that is mainly driven by participatory social media technologies, and it has yet to draw much attention from researchers [80] the managerial implications are in building. At this state of art, the implications for managers and scholars is to highlight the influence of customer-social engagement in knowledge-building process and in performance creation products, services and abilities. 


\section{ACKNOWLEDGMENTS}

The authors wish to thank Dr Giorgio Isabella, the founder of Lux Made, the platform of Social Commerce specializes in Jewelry, Watches and Accessories, and all the other partecipants to our research for their cooperation and willingness to share information with us.

\section{REFERENCES}

[1] Connelly, F. M. (2000.). Narrative inquiry: Experience and story in qualitative research. San Francisco: Jossey-Bass , 6, 94-118.

[2] Stake, R. E. ((1995). ). The art of case study research. Sage.

[3] Yin R. K., 2014, Case Study Research. Design and Methods, USA: SAGE Pubblications.

[4] Surowiecki, J. (2005). The Wisdom of Crowds. Anchor Books.

[5] Geiger, D. S. (2014). Personalized task recommendation in crowdsourcing information system - Current state of the art. Decision Support Systems, 65, 3-16.

[6] Russo-Spena, T. (2012). "Five Co-s" in innovating: a practice-based view. Journal of Service Management, 23(4), 527-553.

[7] Von Hippel, E. (2005). Democratizing innovation. New York: Mit Press.

[8] Sawhney, M. V. (2005). Collaborating to Create: The Internet as a Platform for customer Engagement in Product Innovation. Journal of Internet Marketing, 19(4), 4-17.

[9] Prahalad, C. R. (2004). Co-creation experiences: the next practice in value creation. Journal of Interactive Marketing, 18(3), 5-14.

[10] Prahalad, C. R. (2000). Co-opting customer competecne. Harward Business Review, 78(1), 79-87.

[11] Chesbrough, H. (2011). Bringing open innovation to services. MIT Sloan Manag, 52(5), 85-90.

[12] Bagozzi R.P. (2002). Intentional social action in virtual communities. Journal of Interactive Marketing, 16(2), 2-21.

[13] Gibbert M., L. (2002). Five styles of Customer Knowledge Management, and how smart companies put them into action. European Management Journal, 20(5), 459469.

[14] Kozines, R. (2002). Can consumer escape the market?Emancipatory illuminations from burning man. Journal of Consumer Research, 29(1), 20-38.

[15] Fuller, J. (2006). Why consumer engage in virtual new product develoments initiated by Producers. Advances in Consumer Research, 33, 639-646.

[16] Ashley, C. (2009). Harnessing core business for development impact. Overseas Development Institute, Background Note, February 2009

[17] Barton, D. (2011). Capitalism for the long term. Harvard Business Review, 89(March), 54-91.

[18] Porter, M. E., and Kramer, M. R. (2011). The Big Idea: Creating Shared Value (Digest Summary). Harvard business review, 89(1/2), 62-77.

[19] Sang, M. Lee, David L. Olson, Silvana Trimi, (2012). Co-innovation: convergenomics, collaboration, and co-creation for organizational values, Management Decision, 50 (5), 817 - 831.

[20] Freeman R.E. (2005). The development of stakeholder theory: An idiosyncratic approach.Great minds in management: The process of theory development, 417-435.

[21] Mair, J., Martì, I. (2006). Social entrepreneurship research: a source of explanation, prediction, and delight. Journal of World Business, 41(1), 36-44.

[22] Porter, M.E., Kramer, M.R. (2006). Strategy and society: the link between corporate social responsibility and competitive advantage. Harvard Business Review, 84(12), 78-92.

[23] Michelini, L., Fiorentino, D. (2011). New business models for creating Shared Value. Social Responsibility Journal, 8( 4), $561-57$.

[24] Yang, Chang-Lin, Rong-Hwa Huang, and Yun-Chen Lee. (2014). Building a performance assessment model for social enterprises-views on social value creation. Science Journal of Business and Management, 2(1), 1-9.

[25] Alter, K. (2007). Social enterprise typology, United State: Virtur Ventures LLC.

[26] Kramer, M.R. (2005). Measuring Innovation: Evaluation in the Field of Social Entrepreneurship, United State: Foundation Strategy Group.

[27] Wood, C., Leighton, D. (2010). Measuring Social Value: The Gap between policy and practice. London, UK: Demos. 
[28] Christiansen, N. (2008). Creating Shared Value through basic business strategy, Development Outreach. Washington, DC: World Bank.

[29] World Bank (2012). Creating Shared Value in India: case studies. Prepared for Shared Value workshop participant, November, 2012.

[30] Porter, M. 2012. The New Competitive Advantage: Creating Shared Value. Presentation at the HSM World Business Forum CSV, October 3 2012, accessed at, http://www.isc.hbs.edu/pdf/2012-1003-The_New_Competitive_Advantage.pdf

[31] Benedict R. (1934). Patterns of Culture". New York: Houghton Mifflin.

[32] Kluckhohn, C. (1941). Patterning as Exemplified in Navaho culture, in Language, culture, and personality, Leslie Spier, ed. Menasha, Wisconsin.

[33] Opler, Morris E. 1945. "Themes as Dynamic forces in culture”, American Journal of Sociology, 51: 198-206.

[34] Sang, M., Lee, D., Olson, L., and Trimi, S. 2012. "Co-innovation: convergenomics, collaboration, and co-creation for organizational values", Management Decision, 50(5): 817 - 831.

[35] Camilleri, M.A., (2013). Creating shared value through Strategic CSR in Tourism. LAP Lambert Academin Publishing

[36] Crane, A., Palazzo G., Spence, L. J., Matten, D. (2014). Contesting the Value of "Creating Shared Value, University of California, Berkeley, 56(2), Winter.

[37] Rappaport, A. (1999). Creating shareholder value: a guide for managers and investors. Simon and Schuster

[38] GUATRI L., La teoria di creazione di valore. Una via europea, Milano, Egea, 1991.

[39] Stern, J. M., and Shiely, J. S. (2001). The EVA challenge: implementing value-added change in an organization. John Wiley \& Sons.

[40] Caselli, F., and Feyrer, J. (2005). The marginal product of capital (No. w11551). National Bureau of Economic Research

[41] Freeman, R. E. (2010). Strategic management: A stakeholder approach. Cambridge University

[42] Young, J. (2010, May). Crowd science reaches new heights. The Chronicleof Higher Education May 28, http://chronicle.com/article/The-Rise-of-Crowd-Science/65707/.

[43] Nielsen, M. (2011). Reinventing Discovery: The New Era of Networked Science:. (NU ed.). Princeton, NJ.: Princeton University Press,.

[44] Wiggins, A. C. (2011). From Conservation to Crowdsourcing: A Typologyof Citizen Science. the 44th Hawail International Conferenceon Systems Sciences (HICSS).: the 44th Hawaii International Conferenceon Systems Sciences (HICSS).

[45] Franzoni, C. S. (2004). Crowd science: The organization of scientific research in open collaborative process. Research Policy, 43, 1-20.

[46] Doahn, R. R. (2011). Crowdsourcing systems on the world-wide web. Communications of the ACM , 54(4), 86-96.

[47] Hand, E. (2010). Citizen science: people power. Nature , 466, 685-687.

[48] Dickinson, J. .. (2009). Decisions 2.0: the power of collective intelligence. MIT Sloan Management Review , 50(2), 4552.

[49] Merton, R. (1973). The Sociology of Science: Theoretical and Empirical Investiga-tions. . Chicago, IL.: University of Chicago Press.

[50] Stephan, P. (2012). How Economics Shapes Science. . Cambridge, MA.: Harvard University Press.

[51] Murray, F. O. (2007). Exploring the foundations of cumulative inno-vation: implications for organization science. Organization Science , 18(6), 1006-1021.

[52] David, P. (2008). The historical origins of open science. Capitalism and Society, 3(2).

[53] Sauermann, H. S. (2013). Conflicting logics? A multidimensionalview of industrial and academic science. . Organization Science , 24(3), 889-909.

[54] Dasgupta, P. D. (1994. ). Toward a new economics of science. Research Policy , 23(5), 487-521.

[55] Haeussler, C. J. (2009). Specific and General Informa-tion Sharing Among Academic Scientists, . NBER Working Paper no. 15315.

[56] Howe, J. (2006). The rise of crowdsourcing. Wired Magazine, 14(6), 4.

[57] Howe, J. (2008). Crowdsourcing: Why the Power of the Crowd is Driving the Future of Business,. NY: Crown Business. 
[58] Kleemann, F. V. (2008). Un(der)paid innovators: the commercial utilization of consumer work through crowdsourcing. Sci. Technol. Innov. Stud., 4, 5-26.

[59] Bayus, B. (2013. ). Crowdsourcing new product ideas over time: an analysis of the Dell IdeaStorm community. Managerial Science, 59, 226-244.

[60] Estellés-arolas, E. G.-L.-d.-G. (2012). Towards an integrate crowdsourcing definition,. Journal of Information Science, http://dx.doi.org/10.1177/016555150000000.

[61] Surowiecki, J. (2005). The Wisdom of Crowds. Anchor Books.

[62] Schenk, E. G. (2011). Towards a characterization of crowdsourcing practices, . Journal of Innovative Economics , 7 , 93-107.

[63] Howe, J. (2009). Crowdsourcing: Why the Power of the Crowd Is Driving the Future of Business. New York,: Crown Business,.

[64] Geiger, D. R. (2012). Crowdsourcing information systems - definition, typology, and design. 3rd Int. Conf. Inf. Syst., Orlando, USA.

[65] Wechsler, D. (2014). Crowdsourcing as a method of transdisciplinary research-Tapping the full potential of participants, . Futures , 60, 14-22.

[66] Kleemann, F., Günter Voß, G. and Rieder, K. 2008. "Un(der)paid Innovators: The Commercial Utiliza-tion of Consumer Work through Crowdsourcing". Science, Technology \& Innovation Studies 4 (1): 10-23.

[67] Ordanini, A. M. (2011). Crowd-funding: transforming customers into investors through innovative service platforms", . Journal of Service Management, 22(4), 443 - 470.

[68] Belleflamme, P. L. (2013). Crowdfunding: Tapping the right crowd. . Journal of Business Venturing., 1-25.

[69] Schwienbacher, A. (2010). Crowdfunding of small entrepreneurial ventures. . SSRN Electronic Journal.

[70] Mollick, E. (2014). The dynamics of crowdfunding: An exploratory study. Journal of Business Venturing, , 29(1), 1-16.

[71] Agrawal, A. C. (2011, No. 16820). The geography of crowdfunding. NBER Working Paper,.

[72] Ahlers, G. C. (2012). Signaling in equity crowdfunding. Working Paper.

[73] Lin, M. V. (2013). Home Bias in Online Investments: An Empirical Study of an Online Crowd Funding Marke. (papers.ssrn.com).

[74] Crowdsourcing.org. (2012). Crowdfunding industry report. Market trends, composition, and crowdfunding platforms. . Research Report.

[75] Raupp Musse, S. (2001). Hierarchical model for real time simulation of virtual human crowds. Visualization and Computer Graphics, . IEEE Transactions on, , , 7(2), 152-164.

[76] Adamic, L. A. (2008). "Knowledge sharing and yahoo answers: everyone knows somethings. In Proceedings of WWW 2008 (17th international conference on World Wide Web.

[77] Ponzanelli, L. B. (2013). Leveraging crowd knowledge for software comprehension and development." Software Maintenance and Reengineering (CSMR), . 17th European Conference on. IEEE,

[78] Chao-Min C. Ting-Peng L., E. T. (2014). What can crowdsourcing do for decision support? Decision Support Systems, 65, 40-49.

[79] Yuen, M.-C.S. (2011, ). A survey of crowdsourcing systems. Proceedings of the 3rd IEEE International Conference on Social Computing, pp. 766-773.

[80] Saxton, G. ,. (2013). Rules of crowdsourcing: models, issues, and systems of control. Information System Management, 30(1), 2-20.

[81] Nickerson, R. ,. (2012). A method for taxonomy development and its application in information systems. European Journal of Information Systems.

[82] Tapscott D., W. A. (2006). How mass collaboration changes everything. New (Portfolio ed.). New York: Wikinomics:

[83] Abouzeedan, A., Hedner, T., Klofsten, M. 2010. "Innovation and entrepreneurship - new themes for new times". Annals of Innovation \& Entrepreneurship, 1(1): 1-3.

[84] Brabham, D.C. 2008. "Crowdsourcing as a model for problem solving an introduction and cases". Convergence: the international journal of research into new media technologies, 14(1): 75-90.

[85] Zwass, V. (2010). Co-creation: toward a taxonomy and an integrated research perspective,. Internationa Journal of Electronic Commerce , 15(1), 11-48.

[86] Woisetschläger, D. M., Hartleb, V., and Blut, M. (2008). How to make brand communities work: Antecedents and consequences of consumer participation. Journal of Relationship Marketing, 7(3), 237-256. 
[87] Shang, R. A., Chen, Y. C., and Liao, H. J. (2006). The value of participation in virtual consumer communities on brand loyalty. Internet research, 16(4), 398-418.

[88] Hanekop, H., Wittke, V. (2005). Der Kunde im Internet. In Heike Jacobsen and Stephan Voswinkel (eds.). Der Kunde in der Dienstleistungsbezie-hung. Beiträge zur Soziologie der Dien-stleistung. Wiesbaden: VS Verlag für Sozialwissenschaften, 193-217.

[89] Amit, Raphael and Zott Christoph. 2001. "Value Creation in E-Business", Strategic Management Journal, 22(6/7) Special Issue: Strategic Entrepreneurship: Entrepreneurial Strategies for Wealth Creation (Jun. - Jul., 2001): 493520.

[90] Voß, G. G., and Rieder, K. (2005). Der arbeitende Kunde. Wenn Konsumenten zu unbezahlten Mitarbeitern werden. Frankfurt/New York.

[91] Reichwald, R., Piller, F. 2006. In-teraktive Wertschöpfung. Open Innova-tion, Individualisierung und neue For-men der Arbeitsteilung. Wiesbaden: Gabler.

[92] Stieger, D., Matzler, K., Chatterjee, S., Ladstaetter-Fussenegger, F. (2012). Democratizing Strategy: How Crowdsourcing can be used for Strategy Dialogues. California Management Review, 54( 4), Summer, 2012 CMR.BERKELEY.EDU

[93] Simula, H., Vuori, M. 2012. "Benefits and barriers of crowdsourcing in B2B firms: generating ideas with internal and external crowd", International Journal of Innovation Management, 16(6): 1-29.

[94] Abouzeedan, A., Hedner, T., Klofsten, M. (2010). Innovation and entrepreneurship - new themes for new times. Annals of Innovation \& Entrepreneurship, 1 (1), 1-3.

[95] Scherhorn, G. (977). Konsum. In René König (ed.), Handbuch der empirischen Sozialforschung, Vol. 11: Freizeit Konsum. München, 193-280.

[96] Rosenkranz, D., Schneider, N.F. 2000. Konsum. Soziologische, ökonomische und psychologische Per-spektiven. Opladen: Leske and Budrich.

[97] Vargo, S.L., Lush, R.F. (2004). Evolving to a new dominant logic for marketing. Journal of Marketing, 68, 1-17.

[98] Cova, B., White, T. 2010. "Counter-brand and alter-brand communities: the impact of Web 2.0 on tribal marketing approaches", Journal of Marketing Management, 26: 256-270.

[99] Aiello, L., Cacia, C. "Knowledge Sharing: Crowdsourcing as Enterprise Opportunity" in Enciclopedia of Information Science and Technology, vol. 10, Mehdi Khosrow-Pour Editor, USA:IGIGlobal, 2014

[100] Piller, F. T., Ihl, C., and Vossen, A. (2011). Customer co-creation: Open innovation with customers. Wittke, V./Hanekop, H, 31-63.

[101] Stegbauer, C., Jäckel, M. 2008. "Social Software-Herausforderungen für die mediensoziologische Forschung", Social Software VS Verlag für Sozialwissenschaften: 7-10.

[102] Sawyer, S., Tapia, A. (2005). The socio technical nature of mobile computing work: Evidence from a study of policing in the United States. International Journal of Technology and Human Interaction, 1(3), 1-14.

[103] Afuah, A., Tucci, C. (2012). Crowdsourcing as a solution to distant search. Academy of Management Review, 37(3), 355-375. http://dx.doi.org/10.5465/amr.2010.0146

[104] Kaplinsky R., Morris. M., (2001). A Handbook for Value Chain Research. IDRC.

[105] Parasuraman, A., and Grewal, D. (2000). The impact of technology on the quality-value-loyalty chain: a research agenda. Journal of the academy of marketing science, 28(1), 168-174.

[106] Nair, A. 2005. "Linking manufacturing postponement, centralized distribution and value chain flexibility with performance", International Journal of Production Research, 43(3, 1 February): 447-463.

[107] Stevens, E., (2009), Co-création de valeur et communautés d'utilisateurs : Vers un renouvellement des modèles de chaine de valeur et d'innovation, Revue Management et Avenir, n²8, Sept, pp 230.

[108] Peppard, J., and Rylander, A. (2006). From value chain to value network:: Insights for mobile operators. European Management Journal, 24(2), 128-141.

[109] Mascarenhas, O. A., Kesavan, R., and Bernacchi, M. (2004). Customer value-chain involvement for co-creating customer delight. Journal of consumer marketing, 21(7), 486-496

[110] Thierstein, A., Lu Thi, S., Kruse, C., Gabi, S., and Glanzmann, L. 2008. "Changing Value Chain of the Swiss KnowledgeEconomy: Spatial Impact of Intra-firm and Inter-firm Networks within the Emerging Mega-City Region of Northern Switzerland", Regional Studies, 42(8): 1113-1131.

[111] Caldwell, N. D.; Roehrich, J. K.; Davies, A. C. 2009. Procuring complex performance in construction: London Heathrow Terminal 5 and a Private Finance Initiative hospital, Journal of Purchasing \& Supply Management 15: 178186. 
[112] Schmenner, R. W.; Van Wassenhove, L.; Ketokivi, M.; Heyl, J.; Lusch, R. F. 2009. Too much theory, not enough understanding, Journal of Operations Management 27(5): 339-343.

[113] Zhang, Q.; Vonderembse, M. A.; Lim, J. S. 2002. Value chain flexibility: a dichotomy of competence and capability, International Journal of Production Research 40(3): 561-583.

[114] Chakraborty, S., Dobrzykowski, D., (2014). Examining Value co-Creation in Helthcare Purchasing: a Supply Chain View. Business: Theory and Practice, 15(2): 179-190

[115] Greenberg, P. 2008. CRM at the speed of light. 4th ed. USA: McGraw-Hill Professional.

[116] Lusch, R. F.; Vargo, S. L. (Eds.). 2006. The service- dominant logic of marketing. Armonk, NY: E. M. Sharpe.

[117] Lambert, D. M.; Garcia-Dastugue, S. J.; Croxton, K. L. 2006. Implementing supply chain management, in D. M. Lambert (Ed.). Supply chain management; processes, partnerships, performance. 2nd ed. Sarasota, FL: Supply Chain Management Institute, 217-235.

[118] Cachon, G. P., \& Fisher, M. (2000). Supply chain inventory management and the value of shared information. Management science, 46(8), 1032-1048.

[119] Aldrich, Howard E., and Ted Baker. "Blinded by the cites? Has there been progress in entrepreneurship research." Entrepreneurship 1997 (2000): 377-400.

[120] Busenitz, L. W., West, G. P., Shepherd, D., Nelson, T., Chandler, G. N., and Zacharakis, A. (2003). Entrepreneurship research in emergence: Past trends and future directions. Journal of management, 29(3), 285-308.

[121] Eisenhardt, K. M. (1989). Building theories from case study research.Academy of management review, 14(4), 532-550.

[122] Allison, G. T., and Zelikow, P. (1999). Essence of decision: Explaining the Cuban missile crisis (Vol. 2). New York: Longman.

[123] Cooper, C. R., Cherry, R., Copley, B., Fleischer, S., Pollard, R., and Sartisky, M. (1984). Studying the writing abilities of a university freshman class: Strategies from a case study. New directions in composition research, 19-52.

[124] Piekkari, R., Plakoyiannaki, E., and Welch, C. (2010). 'Good'case research in industrial marketing: insights from research practice. Industrial Marketing Management, 39(1), 109-117.

[125] Siggelkow, N. (2007). Persuasion with case studies. Academy of Management Journal, 50(1), 20-24.

[126] Järvensivu, T., and Törnroos, J. Å. (2010). Case study research with moderate constructionism: Conceptualization and practical illustration. Industrial Marketing Management, 39(1), 100-108.

\section{Author' biography with Photo}

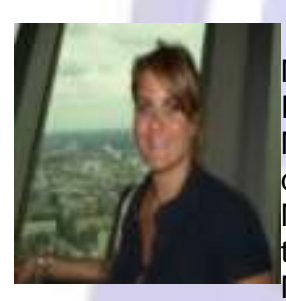

Lucia Aiello is a Researcher Senior in Theory Organization, University of Rome, Italy, Universitas Mercatorum. She is Professor to contract in Business Organization in University of Rome, Sapienza, Italy. She has been Tutor at Faculty of Economy and Management, University of Rome Universitas Mercatorum, Italy. She has conducted training and coaching activities in ENI Spa, Italy. She holds a degree in Tourism Management from University of Naples, Italy, Parthenope (2003), and a Ph.D. in Marketing and Communication from University of Salerno, Italy (2010). Her main research interests are the Accessibility for Cultural Business; the Business Innovation for SMEs; the Human Resources Management. She is Editor for IgiGlobal; Journal JDTA, International Journal of Digital Content Technology and its Applications, Journal ANC, Advances in Network and Communications http://www.humanpub.org/anc/home/editorial.html. She has been Assistant to Conference Program Chairs, (2012-2014), Business Systems Laboratory International, Universitas Mercatorum, Rome, Italy - January 23-24,2014. She has published in international books, journals and conference proceedings. The main publications are "Donne e lavoro in Italia. Considerazioni sulla propensione all'assunzione tra politiche pubbliche e welfare aziendale", Sviluppo e Organizzazione, Gennaio 2014; "Management of Cultural Products: e-Relationship Marketing and Accessibility Perspective", IGI Global, 2014; "Cultural Relationship Management", Business Systems Review, vol. 2(Issue 3), pp. 34-53; II modello organizzativo nello spazio web 2.0. Cina e Italia a confronto nel settore tessile, Italia, Roma: Aracne Editrice Case", in Pantano et all. (editing by), Advanced Technologies Management for Retailing, Usa: IGI Global, p. 145-178, IGI Global.

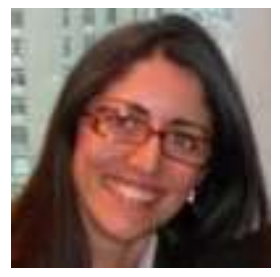

Claudia Cacia is Research Fellow at the Department of Management \& Information Technology, University of Salerno. She has been Post doc Research Fellow in the Department of Business Studies at University of Salerno (Italy). She holds a degree in Business Administration from Bocconi University (Italy) in 2009 and a Ph.D. in Marketing and Communication (Italy) in 2005. Since 2006 she is working in the marketing \&communication field, and also in strategic and business development for many companies (SME). She has been IR associate and marketing specialist in leading companies of italian market. She has teaching and research experience and she has published several articles in academic journals. She has published several book chapters (AICIT, EGEA, et al.) book "Comunicazione economico finanziaria, Investor Relations e creazione di valore. Strumenti per la 
misurazione della qualità delle web investor relations, Giappichelli, Torino, 2010", and other contributes also in Enciclopedya. She has presented research paper, articles and participated in many National and International Conferences. She has served as a Session Chair, and Discussant in a number of International Conferences. She serves as reviewer for international journals, International Journal of Digital Content Technology and Its Application (JDCTA), Jounral of Marketing Principles and Practices of IIMP, International Journal of Monetary Economics and Finance (IJMEF), International Journal of Economic Policy in Emerging Economies (IJEPEE), International Journal of Trade and Global Markets (IJTGM). She is editorial staff member of many Journal (JCIS - JDCTA - IJMPP). Her areas of interest include Management, Financial Communication, Finance, Family Businesses, Entrepreneurship and innovation, Marketing (Innovative use of technologies for Tourism), as well as cultural variables affecting business practices, innovation and adoption of new technology.

\footnotetext{
i Although the views expressed in the paper belong to all of the authors, the paragraphs "Introduction, Licterarure Review, The adopted perspective, Shared Value licterature review, The crowd-creation of value, Knowledge production regimes declinations to a clear classification of "crowd"'are attributed to Claudia Cacia, paragraphs "Participatory tools to value creation, Flexible value chain and role of the "crowd" into the co-creation social value shared, Research methodology: data collection and analysis, Case Study: Lux Made In, Discussion Conclusion and Managerial implications"are attributed to Lucia Aiello and paragraph "Crowdsourcing: the role of web customers for sharing value" to all the authors.
}

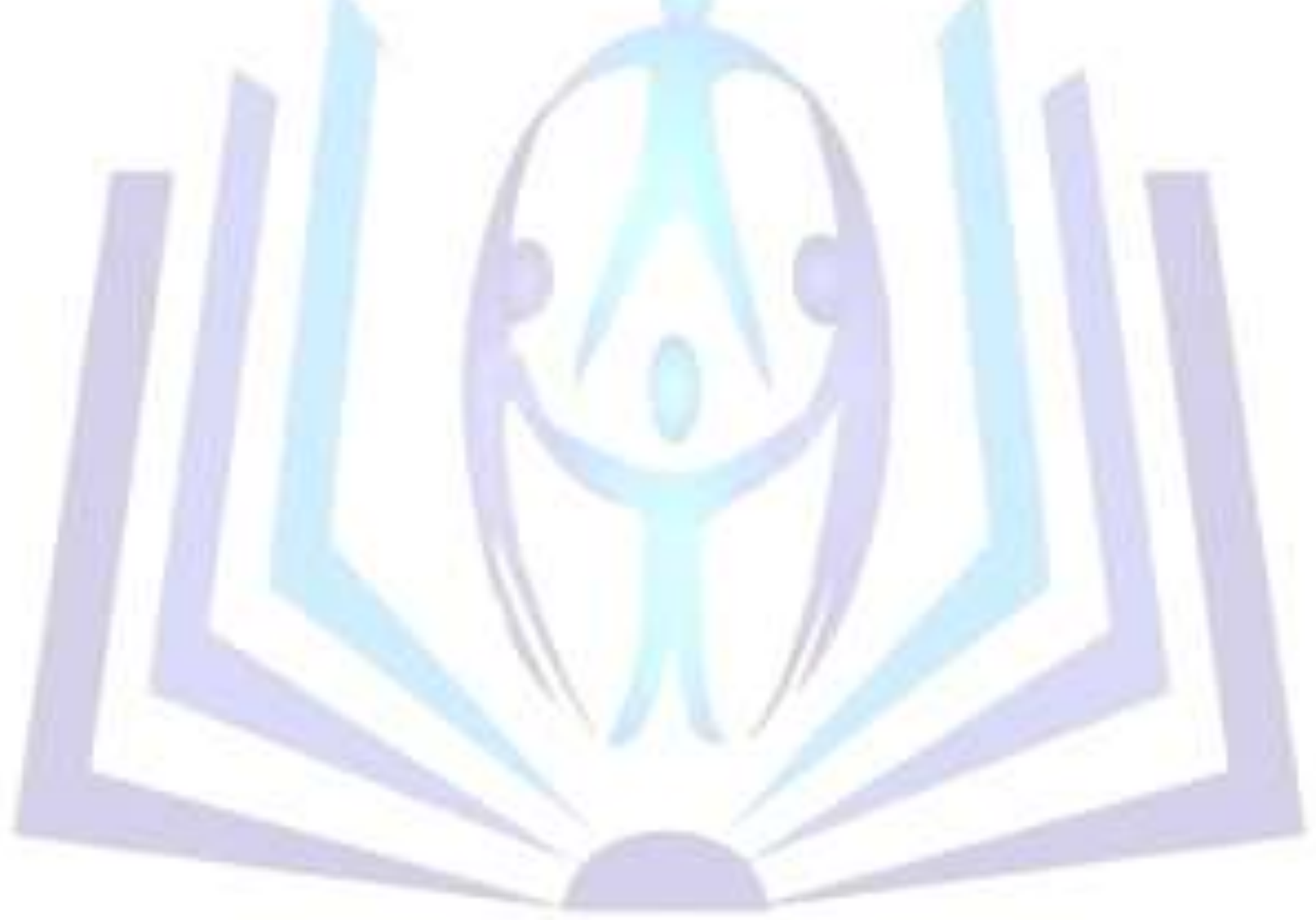

